\title{
"Staying at Home" versus "Working": A Call for Broader Conceptualizations of Parenthood and Paid Work ${ }^{1}$
}

\author{
Elizabeth R. Paré $^{2} \&$ Heather E. Dillaway ${ }^{3}$
}

\begin{abstract}
Using cultural discourse on "stay-at-home" and "working" mothers as a jumping off point, this review essay describes current conceptualizations of parenthood and paid work and critiques the current academic and lay discourses on these topics. The authors highlight the many contradictions between cultural discourse and the reality of parenting and working and call for broader conceptualizations of and more empirical research on what it means to "parent" and "work" in the U.S.
\end{abstract}

Key Words: Motherhood, fatherhood, paid work, stay-at-home mother, working mother, conceptualization, critique

${ }^{1}$ A version of this article was presented at the Society for the Study of Social Problems meetings in Philadelphia, PA, in August 2005. The authors thank Maxine Baca Zinn and anonymous reviewers for helpful suggestions in revising this manuscript.

${ }^{2}$ Elizabeth R. Paré, M.A., is a doctoral student, Department of Sociology, Wayne State University, 2228 Faculty Administration Building, Detroit, MI 48202. Electronic mail may be sent via the Internet at bpare138@wideopenwest.com,

${ }^{3}$ Heather E. Dillaway, Ph.D., is Assistant Professor, Department of Sociology, Wayne State University, 2228 Faculty Administration Building, Detroit, MI 48202. Electronic mail may be sent via the Internet to dillaway@wayne.edu

Every mother-to-be faces the decision of whether to participate in the paid work force while mothering or to disengage from the paid work force and 
make mothering her sole social role. Often this decision is portrayed in terms of whether one will be a "stay-at-home" and presumably "full-time" mother or a "working mother" and therefore one who prioritizes paid work. "The dominant culture portrayal of work and family for women in the United States classifies women as either work oriented or family oriented" (Garey, 1999, p. 6). Thus, women are socially constructed as either mothers or workers, but not both.

Popular media from television images of mothers, advice and self-help books for expectant or new mothers, and news stories on motherhood all rely on this oversimplification. From Eisenberg et al.'s (2002) What to Expect When You Are Expecting which poses work/family as an either-or question, to Iovine's (1997) The Girlfriend's Guide which discusses the "extreme difficulty" new mothers face "trying to combine it all," to W. Sears, M. Sears, R. Sears, \& J. Sear's (2003) Baby Book which promotes a "better baby" through constant contact with the mother, experts continually suggest that women are mothers or workers. Recent news articles about professional women who are "opting out" of paid work in order to mother, or who struggle to balance the two, also perpetuate this dichotomy (Belkin, 2003; Warner, 2005).

Parenting advice books, current news stories, and other forms of popular media help to create a binary between "stay-at-home" and "working" mothers, so that we are unable to conceptualize both statuses in the same person. Experts in popular media as well as academia refer to this rhetoric as an ideological war waging between two camps, with the "stay-at-home" ("good") mother pitted against the "working" ("bad") mother (Douglas, 2000; Hays, 1996; Johnston \& Swanson, 2004). Proponents of each side of this "Mommy War" claim that their approach is the appropriate form of parenting in current times. In addition, both sides argue that society does not see the full value of what women do as mothers whether they are "at home" or "at work." Yet, neither characterization of motherhood necessarily reflects what all mothers actually experience.

We argue, as other feminist scholars have (e.g., Garey, 1999; Hondagneu-Sotelo, 2001; Uttal, 2004), that the dichotomous construction of mother versus worker oversimplifies the complexities of motherhood and work in the current economic system which requires most adults to participate in the workforce. Specifically, it assumes that those who are at home are not participating in the paid work force and that those who are working outside the home are disengaged from being mothers. The reality is not clear cut since stayat-home mothers have varied levels of interaction with their children, complete domestic work without receiving salaried income, and work for paid income either from the home or part-time outside the home (Garey, 1999; Hertz, 1997; Johnston \& Swanson, 2004; Ranson, 2004; Uttal, 2004). Additionally, those who 
are full-time in the paid work force do not disconnect from their role of mother per se and, like those at home, may still consider themselves to be "full-time" mothers (Johnston \& Swanson, 2004). There are various other mother/worker roles that women can occupy as well; these depend on the type of paid work in which one is engaged, the presence/absence of another parent (usually a father), and the racial-ethnic and socio-economic locations of women and families. Thus the landscape that ties the roles of mother and worker together is extremely complex and impossible to dichotomize.

If we study women's experiences as mothers and workers, we discover that there is not a rigid divide with women lining up on one side or the other as suggested by the Mommy War terminology. Motherhood and paid work are intimately intertwined and most women maintain both social roles simultaneously, negotiating the boundaries of each every day. Most women cannot even decide to be a "stay-at-home" mother or "working" mother. The public (outside the home) and private (within the home) do not separate easily in the life of a mother or paid worker.

In this review essay we explore and critique the dichotomous conceptualizations of "stay-at-home" versus "working" motherhood by concentrating on the discrepancies between ideology and experience. We take our lead from feminist scholars such as Anita Ilta Garey (1999), who has done considerable empirical and theoretical work already in pushing the boundaries of how we think about women's motherhood and work activities. Thus, in this endeavor, we attempt to start where she and others have left off in their conceptual work. Our focus in the first part of this article is to review the current ideology surrounding "stay-at-home" and "working" mothers. Second, we critique these ideologies and the mother-work dichotomy by highlighting reasons why mothering and working are not mutually exclusive. While our focus is mostly on the complexities of motherhood and paid work, we include a discussion of fatherhood at the end of this section to illustrate how men may be engaging in similar efforts to balance parenthood and paid work. We argue that fatherhood and paid work may be as intertwined as motherhood and paid work, despite cultural discourse. Third, we explain how recent structural transformations in the economy have necessitated mothers' participation in paid work and fathers' participation in childcare, thus blurring any dichotomy that might exist in our imaginations. After reviewing existing literature and providing this critique, we call for broader conceptualizations of and more empirical research about the lived experiences of parenthood and paid work. We begin by reviewing the cultural discourse on "stay-at-home" and "working" mothers.

Michigan Family Review, 10, 66-87, 2005 C Michigan Council on Family Relations 


\section{The "Stay-at-Home" Mother}

The idea of a "stay-at-home" mother is a modern mainstay in U.S. culture and is often thought of as the "traditional" mother. This image has become an ideal version of what a "true" and "good" mother is and should be. It gained its popularity from the iconic homemaker imagery of the 1950s even as the number of employed women grew (Garey, 1999). Hays (1996) explained that the dominant motherhood ideology in the U.S. today is that of "intensive mothering." There are three main tenets of "intensive mothering" to which all women must adhere if they are to be viewed as "good" mothers: a) childcare is primarily the responsibility of the mother; b) childcare should be child-centered; and c) children "exist outside of market valuation, and are sacred, innocent and pure, their price immeasurable" (Hays, 1996, p. 54).

The "good" mother focuses exclusively on mothering her children and is committed to them in time, energy, and affection (Berry, 1993; Glenn, 1994; Hays, 1996). In other words, a "good" mother is "all-giving" (Thompson \& Walker, 1989). Furthermore, intensive mothering - as an ideology of "childrearing guidelines" - encompasses the view that child rearing should be "expertguided, emotionally absorbing, labor intensive and financially expensive" (Hays, p. 69). Mothers should be ready at all times with "age-appropriate stimulation and interaction; and they should carefully monitor their child's cognitive and emotional development" (Macdonald, 1998, p. 30; see also Berry, 1993; Hays, 1996). Today's "good" mother is at home with her children but also spending physical and psychological "quality time" with them each day to ensure their "proper" development:

Whether the activity is one of the numerous structured momsand-tots programs-swimming, kindergym, dance-or an athome activity - reading, gardening, cooking, playing-the mother's day is to revolve around the child, . . and is to be centered upon the child's educational development. The child is to be involved in any domestic labor performed and the chore at hand is to be transformed into a learning experience for the child (O'Reilly, 1996, p. 90).

Intensive mothering is therefore also considered a full-time job - "a constant responsibility" - at least in a child's early years (Thompson \& Walker, 1989; Macdonald, 1998). It assumes that children require one primary caregiver, that is, the biological or social mother (Berry, 1993; Hays, 1996; Lorber, 1995; Macdonald, 1998; O'Reilly, 1996). "Intensive" mothering presupposes a psychological bond between young children and their mothers and that this 
"umbilical connection" remains "unsevered: that as the primary caregiver, the mother is ideally best suited to comprehend her child's needs and can interpret and respond to those needs intuitively" (Macdonald, 1998, p. 30). Within the "magic circle of ["good"] mother and child," the mother devotes herself to her child and "holds her child's fate in her hands" (Thompson \& Walker, 1989, p. 860).

Indeed, motherhood as ideology and institution presupposes women's and children's interests to be exactly the same (Berry, 1993; Presser, 1995; Rich, 1986). That is, children's needs are mothers' needs. "Good" mothers are supposed to "subsume their own personality to family" which means "having no other real interests, but only substitute or contingent ones, depending on other family member's desires" (Berry, 1993, p. 25). "Mother" becomes an abstract concept in our minds that melds with our expectations for "family" and "gender" and symbolizes the fulfillment of our emotional and physical needs (Lorber, 1995).

Consequently, mothering becomes a career in itself that needs a strong commitment in order for one to be "successful" (Sears, 1999). In this view no other person is able to provide this caregiving. Fathers are seen as incompetent in many types of parenting activities and lacking the "innate" ability to nurture like a mother (Hays, 1996; see also LaRossa, Gordon, Wilson, Bairan, \& Jaret, 1991). Even other women are seen as less able to mother. This mother (usually defined as the biological mother) becomes "indispensable" to the wellbeing of a child. Therefore, while this ever-present mother dedicates herself to producing the welladjusted children possible through continuous nurturing, the father completes his role by providing for the family as an income earner or as a secondary parent in rare moments (Bobel, 2004; Büskens, 2004; Hays, 1996; Hertz, 1997; Johnston \& Swanson, 2004; Mack-Canty \& Wright, 2004). Importantly, the mother does not engage in income-earning activities. She is not only "at home" but also becomes a "true" full-time mother because she is not dividing her time or focus between her employment and her children (Johnston \& Swanson, 2004; Ranson 2004; Sears, 1999; Sears et al., 2003).

Thus the key to understanding the cultural discourse on stay-at-home mothers is to understand that not only are they omnipresent in the home setting but they also are seen as constant mothers, especially because they are not engaging in income-earning activities. Societal norms assume that she is "at home" and "not working" because she prioritizes her family and children above earning income and career advancement. She believes that those nonmaterial acts have more value than earning material objects; indeed, this is seen as her 
"natural" duty. Children's physical and emotional development is her sole priority (Garey, 1999; Hays, 1996; Hertz, 1997; Johnston \& Swanson, 2004).

\section{The "Working" Mother}

On the other side of the dichotomy of motherhood is the "working" mother. This mother gained her popularity during the late 1970s and early 1980s and was seen as the feminist ideal (Douglas, 2000). The term "working" mother suggests a mother who works 40 hours or more a week outside the home and usually in a profession that is career oriented (e.g., lawyer, doctor, CEO). This is the power woman who desires to "have it all." Liberal feminists thought that she would revolutionize the way society saw women and motherhood in the workplace, that eventually the public sphere would alter its practices to combine the roles with ease with such work benefits as flexible work hours, on-site day care, job sharing, and paid time off for parents (Mack-Canty \& Wright, 2004). From this perspective, the "working" mother would become the norm and the "stay-at-home" mother would be the exception. The reality, however, is that worker and mother statuses are not straightforward, and ideologies about the need for paid workers and mothers to be fully dedicated to their tasks in mind and body do not wane. These titles or roles are more complex and difficult to define and manage when one takes into account that work can exist without pay and that mothers and workers can mother and work in any setting. Ultimately, the "working" mother image that liberal feminists have promoted is not the reality most mothers in the paid work force experience.

The working mother is often negatively depicted as a woman concerned more with her own personal success (e.g., maintaining a perfect body, getting a big salary, career advancement) and attainment of material objects (e.g., new car, big house, expensive clothes) than the success of her own children (Johnston \& Swanson, 2004). These mothers are suspect when it comes to the bond and level of attachment they have with their children. They have become "good" workers and "liberated" women by tackling the roles of worker and mother simultaneously and, in the process, have become "bad" mothers because they appear not to practice intensive mothering as fully as stay-at-home mothers and might even allow others to do a "mother's job" (Macdonald, 1998; Uttal, 2002; Wrigley, 1995). Thus, the cultural assumption is that "working" mothers are "prevented by this employment from becoming full-time mothers" (Ranson, 2004, p. 89). Paid work activity, consequently, also prevents them from being "good" mothers. Popular parenting guides, like those by Sears et al. (2003) and Sears (1999), imply that these mothers need to compensate for their "working" status by engaging in "extreme parenting." This compensation may involve "night-time" parenting (enhanced by co-sleeping [sharing sleep space with 
children] and an emphasis on "quality time") and constant strategizing to limit the amount of time away from children (Garey, 1999; Hays, 1996; Sears, 1999; Sears et al., 2003).

The "working" mother is also characterized as a "supermom." The mythic "supermom" is able to switch effortlessly from high-powered career woman to attentive mother/homemaker without sacrificing job or children (DeMeis \& Perkins, 1996; Hays, 1996). Yet the "supermom" image and the very label itself suggests that, when women work outside the home, motherhood should still be their primary duty. Indeed, many "working" mothers see mothering as their primary identity and place family in the same regard as "at home" mothers even if they are not in the home "full-time" (Cinnamon \& Rich, 2002; Johnston \& Swanson, 2004). Paid work is characterized as an ancillary activity compared to motherhood, and working women are still held accountable for the intensive mothering practices that "stay-at-home" mothers supposedly do. While working mothers are skirting their "natural" responsibilities of "full-time" mothering (Büskens, 2004), these "bad" mothers are still supposed to try as much as possible to appear and act like "good," stay-at-home mothers, as intensive mothering is not really optional.

\section{Contradictions within the Dichotomy of Mother and Worker}

Many real-life situations contradict the cultural discourse on "stay-athome" versus "working" mothers as described above. That is, we suggest that there are disconnects between the ideologies and experiences of motherhood and paid work. Below we detail some of the major ways in which mothers' and workers' thoughts and behaviors provide a critique of this ideological dichotomy. Towards the end of this section, we purposely shift from discussing mothers to discussing parents to illustrate that, in our current economy, it is not only difficult to dichotomize mothering and working but also mothering and fathering and fathering and paid work. Ultimately, all forms of parenthood and paid work are intertwined in lived experience, and we may need to reconceptualize more than one set of identities and activities to truly capture the daily lives of women, men, and children.

\section{Stay-At-Home Mothers Feel Pressured to Work}

First, while many in the U.S. champion the mother who opts to "stay at home," and stay-at-home mothers are "good" mothers, there are few social support systems intact to help her maintain this status over time (Hertz, 1997). 
Many mothers feel that they lack the emotional, social, and political support in their decision to be "at home." They feel that they are constantly suspect as "bad" women because they do not work. This feeling of being a female "suspect" occurs even though they are the "ideal" or "good" mothers. Despite fulfilling their ideologically defined gender roles, stay-at-home mothers report feeling pressured to return to work (Johnston \& Swanson, 2004). Hays (1996) also found that many mothers consider childrearing as more challenging than employment outside of the home, partially because child rearing possesses a lesser public value than paid work does within American culture. Child rearing is invisible reproductive labor that does not receive any tangible reward or acknowledgment, despite the cultural assumptions about mothers' responsibility to these activities. The lack of public acknowledgment and the difficulty of child-rearing tasks in general devalue the decisions some women make to be "at home" and makes the role of mother seem lesser than that of paid worker. Thus while we uphold stay-at-home mothers as those "good" mothers, they may feel enough pressure to eventually return to paid work and risk becoming a "bad" mother.

\section{Women Conceptualize Themselves as Mothers First and as Workers Second}

Second, while they do indeed engage in paid work, many mothers do not consider themselves "working" mothers because they work part-time or at night (Garey, 1998; Garey, 1999; Hertz, 1997). These "chameleon mothers" are able to perform both at home and work without social sanctions (Johnston \& Swanson 2004; Garey, 1999). Some "chameleons" maintain their foothold in the professional world while others work in industries that are service-oriented or noncareer-oriented employment. The latter mothers do not have autonomy at work, and their work is considered less prestigious by social standards. They may not even receive benefits as part of this work. Yet maintaining part-time work in the service sector is a way-perhaps the only way - to support their family (see our discussion of economic transformations) (Garey, 1998, 1999). The former mothers may choose part-time work solely for the time it gives them for parenting; these women are aware that they are sacrificing career advancement but believe it is in the best interests of their children and families to do so (Hill et al., 2004; Belkin, 2003). Both groups are engaging in paid work outside the home and thus go against definitions of "good" mothering, yet both also attach less value to their worker status than their mother status and therefore elevate themselves as "good" mothers. Thus, both groups attempt to keep their paid work 
invisible. ${ }^{1}$ While they may acknowledge at times that paid work may be important for their own identities and/or for their families' well being, they still minimize its importance, calling themselves mothers first and foremost.

\section{Diverse Groups of Mothers Have Always Worked Outside the Home}

The connections between mothering and paid work are even more complicated if we specifically look at diverse groups of women by race and social class who cannot even consider staying at home (and therefore may never be labeled "good" mothers). Motherhood discourse assumes there is a privileged status that all mothers possess (e.g., White, college educated, able to pursue a stable career, upper middle class, and married with a spouse who earns a highlevel income) and that this privilege allows them to make clear-cut choices between staying at home or engaging in paid work. Lisa Belkin (2003) sparked a hot debate in The New York Times with "The Opt-Out Revolution," an article that described a growing number of college educated career women "opting-out" of the work force in order to mother. The idea that these women were "opting out" hit a nerve among women who did not or could not make the same "choice." Societal norms expect all mothers to choose mothering over work even though most women do not have real choice in their work status.

Women who are not living in the middle or upper class must work in order to maintain a basic standard of care (e.g., food, shelter, clothing) for their children. These mothers, usually depicted as Black or Latina in our cultural imaginations, are not at home because they cannot afford this luxury. Their only choice is to work and then mother when they can. In fact, if these mothers stayed home with their children they would still be labeled socially unacceptable or "bad" mothers, especially if they were to rely on governmental assistance. As a result, certain groups of women have always worked outside the home for pay, regardless of whether they were mothers simultaneously. Black women have been negotiating the boundaries of paid work and motherhood since slavery (Benin \& Keith, 1995; Collins, 1991). Lower middle-class, working-class, and poor White women have all traditionally worked for income in some capacity in American culture as well, even during the iconic 1950s when women supposedly did not work (Garey, 1999; Kessler-Harris, 1983). Thus the realities of motherhood often are overlooked. We pay more attention to a cultural discourse based on a White, middle- or upper-class experience than the fact that most women are working mothers and have been for a very long time.

\footnotetext{
${ }^{1}$ As Garey (1999) noted when discussing the term "working mother," mother is the noun and working is the adjective; thus it makes sense that women might strive to keep mothering as their primary identity regardless of their paid work behavior.
}

Michigan Family Review, 10, 66-87, 2005 C) Michigan Council on Family Relations 


\section{Mothers Often Mother for Income}

Further, there are two types of women/mothers who perform mothering in return for income, illustrating moments when mothering and working are one and the same. First, there are women/mothers who run in-house daycare facilities, baby sit others' children for income, work as employees in public daycares, and/or are employed in preschool or nursery-school settings. These mothers care for other family's children, either while simultaneously taking care of their own children in their homes or while someone else (most likely another woman, often mother) takes care of their children as they work in a public caregiving facility.

Second, there are growing numbers of women/mothers who work in strangers' private homes as caregivers for others' children. Women in this category could be, for example, nannies or au pairs or other types of "mother's helpers"; yet in each case their paid work duties include the full-time (often 24hour) mothering of others' children which cannot be combined with their own mothering activities. Macdonald (1998) terms this "shadow work," in that while these hired female caregivers do all the work of "intensive mothering" for someone else's children, they are not supposed to take the place of the "real" (biological) mother (see also Wrigley, 1995). "Stay-at-home" mothering, in this scenario, is accomplished by someone other than the mother herself. To contradict the boundaries of motherhood and paid work even more (yet to insure the distinction between the "real" mother and hired mother), this second group of paid caregivers is often of a different racial-ethnic and social class background than the family who hires them. Thus, despite the fact that they are carrying out familial activities, their worker/non-mother status within others' homes is solidified by this lack of privilege (England, 2005; Macdonald, 1998; Wrigley, 1995). Hondagneu-Sotelo (2001) explains further that nannies hired by middleand upper-class, White families in particular areas of the U.S. (e.g., California, New York City) are often immigrant women of color who leave their own children behind in other countries in order to come to the U.S. to care for others' children for income (see also Hondagneu-Sotelo \& Avila, 1997; Wrigley, 1995; Hochschild, 2003; Romero, 1992).

"Transnational mothers" (Hondagneu-Sotelo \& Avila, 1997), as well as all other mothers in this second category and many in the first category, negotiate definitions of themselves as "bad" mothers because they are "working" mothers, as they ironically provide "good," "stay-at-home" care for others' children. All mothers who mother for income face the issue of trying to balance the care of their own children while caring for others' children and may not feel that they are able to the devote "proper" amount of care to either set (perhaps especially their 
own), even if they are "staying at home" while engaging in this paid work (Cochran, 1997; DeMeis \& Perkins, 1996; Hays, 1996; Helburn \& Bergmann, 2002). The complex web of mothering and working relationships created by the fact that women, and often mothers, mother for income shows how intricately combined mothering and working can be in lived experience. As we think about any of the mothers in this web (i.e., those who seek out public or private daycare outside of their home so that they can work outside of their own home, those who bring others' children into their own home to make extra money, those who hire full-time caregivers to take care of children in their own home, and those who are hired as full-time caregivers in others' private homes), it does not make sense to designate some women as "working" and some women as "mothering" because in reality they are all doing both in some fashion. The mere existence of mothering for income and the complex relationships that ensue surely contradict a strict ideological dichotomy of mother and worker.

\section{Work-at-Home Mothers are "Stay-at-Home" Mothers?}

We also must remember that there are many groups of mothers who engage in paid work from the home (and only some of them are engaged in caregiving for income, as in the last example). These mothers maintain their duties as primary caregiver and public worker all from the private sphere of their homes. These women identify themselves, like many of the part-time workers, as "stay-at-home" mothers even though they are participating in paid work and unable to give "full-time" attention or care to their children (Ranson, 2004). The divide between being at work and being at home, then, is constantly blurred. Who is the "working" mother and who is the "stay-at-home" mother, and what do these titles really mean? Mothers who engage in paid work from the confines of their home note that, while they are torn between working and mothering, their presence seems to be enough to balance out the fact that they are unable to devote complete attention and time to their children. Work-at-home mothers, however, assume that they are different from "true" "stay-at-home" mothers who constantly devote attention and time to their children; thus being at home may not be enough to make women feel like "good" mothers (Ranson, 2004).

What these various types of mothers and workers demonstrate is that there are ways of mothering and working outside the dichotomy. Mothers also think of themselves in ways that contradict cultural discourse about their parenting and paid work. Greater attention needs to be paid to mothers' identities, behaviors, and choices when working and mothering, since paid work and motherhood seem to exist more on a continuum than anything else. As Garey (1999) appropriately notes, mothering and working are "woven" together. There is a constant negotiation between the two, and they are not mutually exclusive

Michigan Family Review, 10, 66-87, 2005 C Michigan Council on Family Relations 
tasks or identities (Garey, 1998, 1999; Hays, 1996). Perhaps in reviewing a larger variety of mothering choices and practices, scholars of motherhood could put aside the narrow view that mothers are not the same as workers once and for all. And, if they did not live in the shadow of this dichotomy, mothers themselves might not be at odds with each other, as in the "Mommy Wars" (Hays, 1996; Warner, 2005; Quinlan, 2005). Future empirical research can demonstrate that there are many contradictions within the ideological dichotomy of mothering and working as well as between the ideology and the reality of mothering.

\section{Motherhood versus Fatherhood: Bringing Fatherhood into the Discussion}

If we desire to understand motherhood more fully, though, we need to conceptualize and study fathers more completely as well. There is no lengthy discussion about "Daddy Wars" or a strict cultural discourse defining "stay-athome" fathers and "working" fathers (although both groups of men exist) because the social assumption is that fathers will continue to participate in the paid work force just as they did before they became parents. ${ }^{2}$ This view reinforces the mother as the only parent who needs to decide how paid work affects the family and as the primary parent overall, simply because definitions of mothers are connected to definitions of fathers. Thus, how we have defined fathers over time has reinforced the dichotomy between mother and worker.

Indeed, fathers have been defined as having a secondary and unimportant role in child rearing, when compared to mothers. Many new mothers have been given the advice of "setting dad up for success" meaning give dad a baby that is fed, changed, and happy because dads cannot handle the "dirty" work involved in child rearing. Fathers are continually defined as minimal participants in parenting activities and minor members within the family structure as a whole, outside of the income they provide for its survival (Lorber, 1995; LaRossa et al., 1991; Townsend, 2002). Fathers typically have only gained notice when they reject their economic responsibilities; in this case, they become "bad dads" (Furstenberg, 1988).

Academic interest in fatherhood is fairly new in the last few decades, and therefore there is little empirical or conceptual research on how fathers actually think about and act in the face of fatherhood and whether they also must deal

\footnotetext{
${ }^{2}$ To parallel Garey's (1999) ideas about working mothers, we could say that for fathers, worker is the noun and fathering is the adjective in that men are really "fathering workers." Ideologically, then, becoming a father should not affect paid work as their major responsibility.
} 
with the contradictions between parenthood and paid work (Townsend, 2002). In both popular culture and academic research on parenthood, the focus has remained primarily on motherhood (Forste, 2002; Townsend, 2002). In a recent study of 20 fathers, however, Townsend (2002) found that men may think of fatherhood/parenthood and paid work as a "package deal," that is, more interrelated than cultural discourse allows us to assume. Townsend hints at very much the same argument we make about motherhood and paid work-that fathering/parenting and paid work are not separate entities in meaning or experience. In addition, there is initial evidence of an increasing willingness of fathers to put family before career (Renk et al., 2003) and fathers' changing roles within the family structure (Coltrane, 1996; Forste, 2002; Townsend, 2002). For instance, while fathers may decide (or feel forced) to work more after children are born if the mother steps out of the work force to remain "at home" (Hertz, 1997), we know little about the actual negotiations occurring before or after this decision. There are also fathers who choose to stay at home, but there is little attention given to these men in public conversation; it is assumed that a stay-athome father is simply at home because he is between jobs (Zimmerman, 2000; Pruett, 2001). These studies can only point to the need for more theoretical and empirical research on men's lives and parenthood-work negotiations as a whole.

\section{Structural Transformations in the Economy}

Ideologically, we have tried our best to confine mothers to the private, family sphere and fathers to the public, income-earning sphere, but the lived experiences of parenthood and paid work described in the last section illustrate that our current conceptualizations of these identities/behaviors do not fit with reality. Structural theorists reason that "the current economic system is no longer congruent with traditional family values," thus making the labels of "good" and "bad" parents even more unfair and restrictive (Dill et al., 1998, p. 9; Mann et al., 1997; Smith, 1993). This section comprises a brief review of some of the recent economic transformations in the U.S. We concentrate mostly on how the market economy is now global and few U.S. jobs are secure. Consequently, we attempt to explain why more women and men are combining parenting and work out of necessity and how this reality must encourage us to critique dichotomous conceptualizations of parenthood and paid work.

Due to advancements in computer technology and the elimination of tariffs/trade barriers (in agreements like NAFTA and GATT), the market economy is now "global" (Baca Zinn \& Eitzen, 2005). The flow of raw materials, finished products, and information across national and international boundaries has changed the geography and pace of the contemporary workplace (Baca Zinn \& Eitzen, 2005; England, 1996; Hochschild, 1997). U.S. companies only employ 
about 14 percent of their manufacturing workforces within our country now, as companies move to low-wage countries looking for cheaper employees and transfer corporate monies elsewhere (Baca Zinn \& Eitzen, 2005). Although corporate decisions appear beneficial for those in the new location, "they also take investment away from others" (Baca Zinn \& Eitzen, p. 97), that is, workers, families, communities, and suppliers in the U.S.

Fewer and fewer low-skill manufacturing jobs are performed within the United States. Furthermore, those who still work in manufacturing within this country can continue to expect forced early retirements and/or frequent layoffs due to the foreign competition U.S. companies face. Outsourcing of informationbased goods and services now affects the availability of other white-collar jobs in the U.S. as well (e.g., engineering, computer technology, communications, accounting, customer service, and telemarketing), as more and more companies find it cheaper to base their services and production elsewhere (Baca Zinn \& Eitzen, 2005). Thus, many service sector jobs that have been considered safe are now vulnerable as well. Finally, as major companies continue to leave U.S. locations, smaller, local businesses left in those locations suffer economically (because of a lack of stable infrastructure and customer base); this puts minimum wage jobs in jeopardy. Almost no U.S. job is secure in the current economic climate.

How do these contemporary structural changes in the economy affect the experiences of mothers and fathers, and how we think about them? First, families are affected when male "good providers" lose their jobs (Baca Zinn \& Eitzen, 2005; Newman, 1994; Rubin, 1994; Wilson, 1996). While fathers may be physically present in the home more often after being laid off, this does not secure their "good" father status; rather being laid off counteracts it. Recent research on fathers shows the excessive self-esteem problems former "good providers" face in reaction to being laid off from jobs that paid a "family wage" that supported the family (Rubin, 1994; Newman, 1994). This loss of the provider role is also problematic since there is no other role for men conceptually (Coltrane, 1996; Rubin, 1994). Some men may become more "involved" with their children and see active fathering as the immediate solution (Coltrane, 1996). Nonetheless, on average men have trouble making the transition from being a sole provider to social "co-parent" and (perhaps) "co-provider" (Coltrane, 1996). While men are dealing with the contradictions between old and new identities, their female counterparts (i.e., mothers) are pressured to maintain paid work in order for families to survive.

Second, since the median hourly wage of American employees (especially for men) has dropped since the 1970s and underemployment, as well 
as unemployment, has increased because of changes in the economy, the middle class is "shrinking" (Baca Zinn \& Eitzen, 2005; Dill et al., 1998). U.S. families also have fewer health care benefits, paid vacation days, less sick leave and less discretionary income available to them when negotiating family and work roles (Baca Zinn \& Eitzen, 2005). This means that many families who were once defined as "middle-class" in this country are now experiencing "downward mobility" and a declining standard of living (Baca Zinn \& Eitzen, 2005; Newman, 1994; Rubin, 1994). These families that "fall from grace" must renegotiate work-family roles outside of stereotypical gender roles (Newman, 1994; Baca Zinn \& Eitzen, 2005; Rubin, 1994). For example, a shift to dual incomes seems to be the most popular "coping strategy" for families (Baca Zinn \& Eitzen, 2005). An increasing trend towards home-based work (especially among mothers) is another common coping strategy (Baca Zinn \& Eitzen, 2005). Downward mobility in the face of economic changes and families' strategies for coping, then, contradict both "stay-at-home" motherhood and "working" fatherhood.

Finally, not only is the middle class shrinking but also poverty is increasing. This is especially true among households headed by racial-ethnic minorities and women (Baca Zinn \& Eitzen, 2005; Edin \& Lein, 1997; Wilson, 1996) due to gender and race gaps in pay, glass ceilings for women and other minorities, and the lack of high-paying low-skilled jobs in the service sector. Baca Zinn and Eitzen (2005) suggested that even minimum-wage jobs that were available after the 1996 welfare reform laws are no longer stable because these jobs were often in industries hit hard by the fallout from September $11^{\text {th }}$ (e.g., travel, tourism, and retail) and an economy that continues to decline. Thus while racial-ethnic minorities and lower-income women have always worked (Baca Zinn \& Eitzen, 2005; Benin \& Keith, 1995; Collins, 1991; Kessler-Harris, 1983), their income-earning efforts are typically not enough to pull their families out from poverty. Particular groups of mothers therefore have no access to the "good" mother label, since they a) cannot uphold the tenets of stay-at-home mothering; b) work outside the home in stable jobs; and c) are poor. Furthermore, racial-ethnic fathers are automatically deemed "bad" due to their lack of connection to a secure, stable labor market.

Dill et al. (1998) cite a 1997 USA Today article that explains how "the traditional" family is being "destroyed by a modern economic system" ..."[The] economic system simply won't allow families to exist in the 'old-fashioned' way, with a father who generates most of the earnings and a mother who does most of the nurturing. The one-earner middle-class family is extinct" (p. 10). This argument that class structure and changes in the economy undermine families today by taking mother out of the home is becoming more widespread within 
sociology and family studies (Dill et al., 1998). However, ideology ignores economic structural constraints and even reinforces or legitimates them. It becomes even harder to be a "good" parent (or a "good" worker, for that matter) when these constraints are present.

\section{A Need to Reconceptualize Both Parents and Workers}

If we continue to view parents and workers via the existing ideological dichotomies, we place monolithic, unrealistic definitions and expectations on parents and workers and overlook the lived experiences of individuals and families. Motherhood identities and behaviors vary and the literature needs to more fully reflect this finding. Paid work identities and behaviors also vary. Finally, fatherhood and men's work behavior varies. The polarized opposites bantered about in the "Mommy Wars" do not accurately demonstrate the realities in which women (and men) find themselves trying to negotiate. Yet it is from the ideological basis of the "Mommy Wars" that cultural discourse and most academic literature starts to assess the mothering experience. By starting with this dichotomy, we narrowly characterize women's experiences of family and paid work and altogether ignore men's current family and work situations.

Recently Newsweek (Quinlan, 2005; Warner, 2005) featured two articles on motherhood and the quest to balance the role of mother and role of worker with perfection. Each article's author, like other journalists and academic researchers, pointed to the problems that each side of the "Mommy War" faces: "stay-at-home" mothers feel the need to justify their station as equivalent to a professional career. On the flipside, "working" mothers feel they must keep their worker status and mother status from overlapping too much, so as to always be "good" mothers. These articles also go further by suggesting that both of these mothers are trying to complete a version of the "supermom" but have different ideas on what that is. This is similar to Johnston and Swanson's (2004) conclusion that the "supermom" image is internalized by all sides of the mothering debate, creating a negative divide between women based on a binary conceptualization of motherhood that does not exist. It builds on DeMeis and Perkins' (1996) argument that mothers are not creating simply their own mothering identities but listening to outside normative sources on what mothering is and what kind of mother they are. These news stories on the "Mommy Wars" and the academic literature on motherhood and paid work experiences therefore suggest that there are serious implications to promoting a dichotomous conceptualization of motherhood. Perhaps most importantly, it divides women into groups that compete against each other for the "good" mother title without enough weight given to the economic or social structures and everyday realities that are in place helping to contradict the "good" versus "bad" 
mother (or "mother" versus "father") divide. Secondly, fathers are left out of a discussion of the negotiations between parenthood and paid work, and this hinders positive identities and successful family-work negotiations in the current economy.

Instead of promoting a divisive ideology and contradictory dichotomies, feminist scholars, journalists, and lay parents and workers need to focus on the connections across mothering, fathering, and working experiences, and the common negotiations adults face as they engage in parenting and paid work. We have not addressed the ideas that mothers seem to universally share the home as their central focus and, regardless of employment, see activities within the home as a woman's responsibility (Garey, 1999). A redirection of the conceptualization of mothering and work would allow for women to see motherhood not as a competitive sport, but as a practice that needs support across the social and political spectrum. Not only do those shaping the issue in the public realm need to alter their conceptualization of motherhood, fatherhood, and paid work, but feminist and family scholars need to further document the realities of parenting and work and the continuum of identities and behaviors falling under each.

Defining child rearing as a mother-only, in-home activity also privatizes the parenting activities and parenting issues, isolating individuals in their efforts to care for children and engage in paid work (Hertz, 1997). This stops mothers and fathers from being able to negotiate and balance the roles of parent and worker in their everyday lives and receive social support for these roles. We argue that both parenting and work-along with the economic transformations that surround each-should be considered public issues that affect us all. Ultimately this will mean moving beyond the gendered ideological boundaries set for parenting as well as normative constructions of what it means to "work" Simultaneously we should rethink our notions about physical space and what it means to be "at home" or "at work" as one parents and/or earns income. As scholars, workers, and (in the case of many of us) parents, we have much reconceptualization and exploratory work to do. 


\section{References}

Baca Zinn, M., \& Eitzen, S. D. (2005). Diversity in families $\left(8^{\text {th }}\right.$ ed.). Boston, MA: Allyn $\&$ Bacon.

Belkin, L. (2003). The opt-out revolution. New York Times Magazine (October 26).

Benin, M., \& Keith, V. (1995). The social support of employed African American and Anglo mothers. Journal of Family Issues, 16, 275-297.

Berry, M. F. (1993). The politics of parenthood: Child care, women's rights, and the myth of the good mother. New York: Penguin Books.

Bobel, C. (2004). When good enough isn't: Mother blame in The Continuum Concept. Journal of the Association for Research on Mothering, 6, 68-78.

Büskens, P. (2004). The impossibility of "natural parenting" for modern mothers. In A. O'Reilly (Ed.), Mother matters: Motherhood as discourse and practice (pp. 98-110). Toronto, ON: Association for Research on Mothering.

Cinnamon, R., \& Rich, Y. (2002). Gender differences in the importance of work and family roles: Implications for work-family conflict. Sex Roles, 47, 531-541.

Cochran, E., \& Cochran, M. (1997). Child care that works. New York: Houghton Miflin.

Collins, P. H. (1991). Black feminist thought: Knowledge, consciousness, and empowerment. New York: Routledge.

Coltrane, S. (1996). Family man: Fatherhood, housework and gender equity. New York: Oxford University Press.

Demeis, D., \& Perkins, H. (1996). "Supermoms" of the nineties: Homemaker and employed mothers' performance and perceptions of the motherhood role. Journal of Family Issues, 17, 777-792.

Dill, B. T., Baca Zinn, M., \& Patton, S. (1998). Valuing families differently: Race, poverty and welfare reform. Sage Race Relations Abstracts, 23(3), 4-30.

Douglas, S. (2000). The Mommy Wars: How the media turned motherhood into a catfight. Ms. Magazine (February/March).

Edin, K., \& Lein, L. (1997). Making ends meet: How single mothers survive welfare and low-wage work. New York: Russell Sage Foundation.

Michigan Family Review, 10, 66-87, 2005 C Michigan Council on Family Relations 
Eisenberg, A., Hathaway, S., \& Murkoff, H. (2002). What to expect when you're expecting. New York: Workman.

England, K. (1996). Mothers, wives, workers: The everyday lives of working mothers. In $\mathrm{K}$. England (Ed.), Who will mind the baby? Geographies of child care and working mothers (pp. 109-122). New York: Routledge.

England, P. (2005). Emerging theories of care work. Annual Review of Sociology, 31 (14), 381-400.

Feree, M. M. (1990). Beyond separate spheres: Feminism and family research. Journal of Marriage and the Family, 52(4), 866-884.

Forste, R. (2002). Where are all the men? A conceptual analysis of the role of men in family formation. Journal of Family Issues, 23, 579-600.

Furstenberg, F. F., Jr. (1988). Good dads-bad dads: Two faces of fatherhood. In J. L. Palmer \& I. V. Sawhill (Eds.), The changing American family and public policy (pp. 193-218). Washington, DC: Urban Institute Press.

Garey, A. (1998). Constructing motherhood on the night shift: "Working mothers" as "stay-at-home moms." In K. V. Hansen \& A. I. Garey (Eds.), Families in the U.S.: Kinship and domestic policies (pp. 709-726). Philadelphia, PA: Temple University Press.

Garey, A. (1999). Weaving work \& motherhood. Philadelphia, PA: Temple University Press.

Helburn, S., \& Bergmann, B. (2002). America's child care problem. New York: Palgrave.

Hertz, R. (1997). A typology of approaches to child care: The centerpiece of organizing family life for dual-earner couples. Journal of Family Issues, 18, 355-385.

Hill, E. J., Ferris, M., \& Martinson, V. (2004). New-concept part-time employment as a work-family adaptive strategy for women professionals with small children. Family Relations, 53, 282-292.

Hochschild, A. (with Machung, A.) (1989). The second shift. New York: Avon Books.

Hochschild, A. (1997). The time bind: When work becomes home and home becomes work. New York: Metropolitan Books.

Hochschild, A. (2000). The nanny chain. The American Prospect, 11, 32-26.

Michigan Family Review, 10, 66-87, 2005 C Michigan Council on Family Relations 
Hochschild, A. (2003). The commercial spirit of intimate life: Notes from home and work. Berkeley, CA: University of California Press.

Hondagneu-Sotelo, P. (2001). Domestica: Immigrant workers cleaning and caring in the shadows of affluence. Berkeley, CA: University of California Press.

Hondagneu-Sotelo, P., \& Avila, E. (1997). "I'm here, but I'm there": The meanings of Latina transnational motherhood. Gender \& Society, 11(5), 548-571.

Iovine, V. (1997). The girlfriends' guide to surviving the first year of motherhood. New York: Berkley Publishing.

Johnston, D., \& Swanson, D. (2004). Moms hating moms: The internalization of mother war rhetoric. Sex Roles, 51, 497-510.

Kessler-Harris, A. (1983). Out to work: A history of wage-earning women in the United States. New York: Oxford University Press.

Kroska, A. (2004). Divisions of domestic work: Revising and expanding the theoretical explanations. Journal of Family Issues, 25, 901-932.

LaRossa, R., Gordon, B. A., Wilson, R. J., Bairan, A., \& Jaret, C. (1991). The fluctuating image of the 20th century American father. Journal of Marriage and the Family, 53, 987-997.

Lorber, J. (1995). Rocking the cradle: Gendered parenting. In J. Lorber (Ed.), Paradoxes of gender. New Haven, CT: Yale University Press.

Macdonald, C. L. (1998). Manufacturing motherhood: The shadow work of nannies and au pairs. Qualitative Sociology, 21(1), 25-48.

Mack-Canty, C., \& Wright, S. (2004). Family values as practiced by feminist parents: Bridging third-wave feminism and family pluralism. Journal of Family Issues, 25, 851-880.

Mann, S. A., Grimes, M. D., \& Kemp, A. A. (1997). Paradigm shifts in family sociology? Evidence from three decades of family textbooks. Journal of Family Issues, 18, 315349.

Newman, K. S. (1994). Troubled times: The cultural dimensions of economic decline. In M. A Bernstein \& D. Adler (Eds.), Understanding American economic decline. New York: Cambridge University Press.

O'Reilly, A. (1996). Ain't that love? Antiracism and racial constructions of motherhood. In M. T. Reddy, (Ed.), Everyday acts against racism. Seattle, WA: Seal Press. 
Presser, H. B. (1995). Are the interests of women inherently at odds with the interests of children or the family? A viewpoint. In K. O. Mason \& A. M. Jensen (Eds.), Gender and family change in industrialized countries (pp. 297-319). New York: Clarendon Press.

Pruit, K. (2001). Father need: Why father care is as essential as mother care for your child. New York: Broadway.

Quinlan (2005). Memo to mothers: Have a good time. Newsweek (February), 50-51.

Ranson, G. (2004). Paid work, family work and the discourse of the full-time mother. In A. O'Reilly (Ed.), Mother matters: Motherhood as discourse and practice (pp. 8797). Toronto, ON: Association for Research on Mothering.

Renk, K., Roberts, R., Roddenberry, A., Luick, M., Hillhouse, S., Meehan, C., Oliveros, A., \& Phares, V. (2003). Mothers, fathers, gender role, and time parents spend with their children. Sex Roles, 48 (7-8), 305-315.

Rich, A. (1986). Of woman born: Motherhood as experience and institution. New York: Norton.

Riggs, J. (1997). Mandates for mothers and fathers: Perceptions of breadwinners and caregivers. Sex Roles, 37, 565-580.

Rubin, L. (1994). Families on the fault line: America's working class speaks about the family, the economy, race, and ethnicity. New York: HarperCollins.

Sears, W., Sears, M., Sears, R., \& Sears, J. (2003). The baby book: Everything you need to know about your baby from birth to age two ( $2^{\text {nd }}$ ed.). New York: Little Brown.

Sears, W. (1999). Nighttime parenting: How to get your baby and child to sleep. New York: Plume Books.

Smith, D. (1993). The standard North American family: SNAF as an ideological code. Journal of Family Issues, 14(1), 50-65.

Thompson, L., \& Walker, A. J. (1989). Gender in families: Women and men in marriage, work, and parenthood. Journal of Marriage and the Family, 51(4), 845-871.

Townsend, N. W. (2002). The package deal: Marriage, work, and fatherhood in men's lives. Philadelphia, PA: Temple University Press.

Uttal, L. (2002). Making care work: Employed mothers in the new childcare market. New Brunswick, NJ: Rutgers University Press.

Warner, J. (2005). The mommy madness generation. Newsweek (February), 42-49. 
Wilson, W. J. (1996). When work disappears: The world of the new urban poor (pp. 87111). New York: Vintage Books.

Wrigley, J. 1995. Other people's children: An intimate account of the dilemmas facing middle-class parents and the women they hire to raise their children. New York: Basic Books.

Zimmerman, T. (2000). Marital equality and satisfaction in stay-at-home mothers and stay-at-home father families. Contemporary Family Therapy, 22, 337-354. 